\title{
Predation on epigeic, endogeic and anecic earthworms by carabids active in spring and autumn
}

\author{
LUCIJA ŠERIĆ JELASKA ${ }^{1}$ \\ WILLIAM O. C. SYMONDSON² \\ ${ }^{1}$ Faculty of Science, University of Zagreb, \\ Rooseveltov trg 6, 10000 Zagreb, Croatia \\ ${ }^{2}$ Cardiff School of Biosciences, Cardiff University, \\ Sir Martin Evans Building, Museum Avenue, Cardiff, \\ CF10 3AX \\ Correspondence: \\ Lucija Šerić Jelaska \\ e-mail: slucija@biol.pmf.hr
}

Key words:

Beneficial soil fauna, earthworm ecotypes, molecular gut content analyses, multiplex PCR, predatory insects

\begin{abstract}
Background and purpose: Generalist predatory carabid beetles can control the abundance of a range of prey species within ecosystems, including certain pests. In terms of bio-control, these unspecialised predators may be sustained in the field when pest populations are low by predating on other animals such as earthworms. The aim of this study was to reveal patterns in predation by a community of carabids in the field on different earthworm species with respect to anecic, endogeic and epigeic earthworm ecotypes.
\end{abstract}

Materials and methods: We utilised DNA extracted from the gut content of 23 carabid species to reveal predation on earthworms directly in the field, comparing spring and autumn active species. The DNA was then screened using PCR with five earthworm species-specific primers.

Results and discussion: Our results show that 20 species, which accounted for $53 \%$ of all tested individual beetles, were positive for earthworms, with similar proportions in the spring and autumn samples and between the sexes. Earthworms from all three ecotypes were confirmed within the predator guts and were widely consumed within the carabid community.

Conclusions: These results suggest that predation on earthworms might be an important mechanism sustaining populations of generalist predatory carabids in the field, which can be advantageous for biological control. Therefore, management systems that maintain a healthy soil with all three ecotypes of earthworm present is likely to be beneficial for carabids and indirectly for control of plant pests.

\section{INTRODUCTION}

Drevious studies on gut content analyses and field observations have 1 confirmed that predatory carabid beetles feed mainly on soil invertebrates such as earthworms, slugs, snails, woodlice, springtails and various insects (e.g., 1, 2, 3, 4, 5, 6, 7, 8, 9, etc.). As such, carabids can in theory contribute to the control of pests and/or invasive alien species within ecosystems by predation (e.g., 10, 11, 12, 13, 14, 15, 16, 17 etc.). Still we lack some more precise information about their consumption of pests but also of other animals that help to sustain beneficial predatory carabids in the field when pest populations are low.

Many adult carabid beetles, as well as their prey, are active in the upper soil layers, the soil surface and the litter layer, where they feed. Although some carabid species can dig (i.e., Scarites spp.) or use holes that are already present in the soil to move deeper into the substrate (18), most of them search for food on the soil surface.

Earthworms, however, exhibit some degree of vertical stratification within the soil and can be categorized into epigeic, endogeic and anecic 
ecological groups. Epigeic species live on the soil surface, where they feed on leaf litter and usually do not make burrows (e.g., Lumbricus rubellus, Lumbricus castaneus, Satchellius mammalis) (19). Endogeic species make horizontal burrows through the upper part of the soil (e.g., Allolobophora chlorotica) (19). Anecic earthworms live deeper, but make vertical burrows in the soil, where they feed on leaves that they drag into their burrows from the soil surface (e.g., Lumbricus terrestris and Aporrectodea longa) (19). In European soils, the earthworm population is characterised by a mean density of -100 individuals per $\mathrm{m}^{2}$ and a mean biomass of $5 \mathrm{~g}$ dry weight per $\mathrm{m}^{2}$ and therefore contributes significantly to soil biomass (20).

Although, earthworms compose the main component of the diet of many carabid species $(8,9)$ and may improves fitness parameters in some carabid species (6), the patterns in predation by a community of carabids in forest ecosystem on different earthworm species with respect to anecic, endogeic and epigeic earthworm ecotypes have not been studied jet.

Carabids differ in morphological (e.g. procerisation, cychrisation) and ecological traits (e.g. olfactory or visual hunters, winged or wingless specimens) and seasonal breeding and feeding activity $(2,21)$, and these differences may affect their diets. Members of the same species may even change their diet through the year. For example, it was confirmed that Carabus violaceus may switch from a mainly earthworm diet in the spring to a slug-based diet in the autumn (22).

To overcome the shortcomings of classical methods (e.g., direct observations in the field, microscopic analysis of the gut contents) we utilised molecular methods to detect with high precision the semi-digested DNA from different earthworm species in the carabid gut (e.g., 7, 15, 23, 24, 25).

Taking into account differences in the traits of carabid species within a community and predation on the three ecological types of earthworms, we screened a gut content of a range carabid species collected in the field in late spring/early summer and in autumn in two PCR multiplex assays (7) for carabid diet analysis. Our assays comprises already designed and optimised nine primer pairs (7) to target five earthworm species, each species belonging to one of the three ecological groups of earthworms.

Considering carabids' generalist feeding, we hypothesise that in addition to the epigeic and endogeic earthworms located in the upper soil, adult carabids may also predate on anecic earthworms when these earthworms collect leaves from the soil surface.

\section{MATERIALS AND METHODS}

\section{Material used for molecular analyses}

All invertebrates were collected from five sites located in deciduous woodlands (two sites in Croatia, in Mt.
Medvednica near Zagreb, and three sites located in woodland patches surrounded by arable fields in Wales, UK, one in Llantrisant and two in Rudry. Earthworms were sampled from the topsoil layer in three visits in spring and three in autumn in both 2007 and 2010 by digging and hand collection (using five $50 \mathrm{~cm}^{2}$ quadrats per site to a depth of $10 \mathrm{~cm}$ ). All collected earthworms were maintained in separate Petri dishes containing moist filter paper to empty their guts for 24 to 48 hours. They were then killed at $-80^{\circ} \mathrm{C}$. Pitfall trapping and hand sampling were used to collect adult carabid beetles. As described in Šerić Jelaska et al. (8), five traps ( $0.5 \mathrm{~L}$ plastic cups containing no preservative) at each site were deployed for approximately three weeks from May until the end of June and again for three weeks from mid-September until the end of October. Trapping was conducted in 2007 in Croatia and in 2010 in the UK. The traps were emptied every morning, and each individual beetle was placed into a plastic tube and killed at $-80^{\circ} \mathrm{C}$. All carabid beetles and adult earthworm specimens were identified to the species level based on their morphological characteristics using identification keys (19, 26, 27, 28). Beetles were also sorted by sex.

DNA from collected earthworm species was extracted using the DNeasy Blood \& Tissue Kit (Qiagen), and used as a positive control during gut content analyses. Additionally, we extracted the DNA from another 35 soil invertebrate species representing non-target potential prey from the field (the same set of animals was used in Šerić Jelaska et al. 2014 a, b, cf Supporting Information). All primer pairs were thus tested for cross-amplification against carabid predator DNA as well as against the DNA of other soil invertebrate taxa. The non-target organisms were tested individually, and cross-amplifications were not found, confirming that the primers were specific to the prey species for which they were designed.

Prior to molecular analyses, carabid foreguts were dissected as described in Symondson et al. (5). Carabid specimens collected in UK were weighed before and after the dissection. DNA from foreguts was extracted using DNeasy Blood \& Tissue Kit (Qiagen).

All extractions were tested for the presence of DNA in the previous work of Šerić Jelaska et al. (8) by PCR using general invertebrate primers for a $710 \mathrm{bp}$ fragment of the mitochondrial cytochrome oxidase I (COI) gene (29), and all conditions were described in detail in Šerić Jelaska et al. (8).

\section{Screening of field-caught predators to identify earthworms in predator guts}

To screen the gut contents of the field-caught carabids, we used earthworm species-specific primer pairs (7) for five common species belonging to the three ecological groupes: epigeic Lumbricus castaneus and $L$. rubellus, endogeic Allolobophora chlorotica, and anecic Aporrectodea longa and L. terrestris. For Allolobophora chlorotica we used primer pairs designed for five lineages of the species (Table 1). 
Table 1. Details of primer sequences (5'-3') used in two PCR multiplex assays (assay A with primers for multiple A. chlorotica lineages and assay $B$ for other four earthworm species) (King et al. 2010).

\begin{tabular}{|c|c|c|c|c|}
\hline Species & Multiplex & Primer name & Primer sequence & Amplicon size (bp) \\
\hline \multirow[t]{10}{*}{ Allolobophora chlorotica } & A & COI AchL1F4 & AAATTGATTACTACCYCTG & 231 \\
\hline & & COI AchL1R2 & GAAGCACCTGCTAGRTGG & \\
\hline & & COI-AchL2A-F5 & TGCAGTAGAAAAGGGTGCG & 151 \\
\hline & & COI-AchL2A-R3 & AGTAATAAAATTAATGGCA & \\
\hline & & COI-AchL2B-F3 & САТСАСТААТССТТСТАGTG & 126 \\
\hline & & COI-AchL2B-R3 & AGAAGATAGCTAAGTCTACG & \\
\hline & & COI-AchL3-F2 & TGGAAATTGACTATTACCAC & 261 \\
\hline & & COI-AchL3-R2 & ATGAAATTAATTGCCCCGAG & \\
\hline & & COI-AchL4-F2 & CСAACTATATAATACTATCGTT & 152 \\
\hline & & COI-AchL4-R2 & ATCTCATGTTATTGAGTCGA & \\
\hline \multirow[t]{2}{*}{ Aporrectodea longa } & B & COI-Al-F2 & TGGCTTCTACСТCTAATACT & 213 \\
\hline & & COI-Al-R2 & ATGAAGGGAGAAGATGGCCA & \\
\hline \multirow[t]{2}{*}{ Lumbricus castaneus } & B & COI-Lc-F2 & ААСТGАСТССТСССАСТААТ & 189 \\
\hline & & COI-Lc-R2 & AGAAGGTCCTGCGTGAGCT & \\
\hline \multirow[t]{2}{*}{ L. rubellus } & B & COII-Lr-F3 & AGACGGTAATCTCCTGGAAGT & 164 \\
\hline & & COII-Lr-R2 & СТTCGTATTCTCTATATCACA & \\
\hline \multirow[t]{2}{*}{ L. terrestris } & B & COII-Lt & GAATCTATTTCYACATTTAAGAA & 256 \\
\hline & & COII-Lt-R2 & CGGCTATGCTCTYCTAGCAC & \\
\hline
\end{tabular}

Two diagnostic multiplex PCRs were used to screen the gut of each field-caught beetle for the presence of multiple earthworm species. The earthworm primers (7), combined in 2 multiplex reactions, are listed in Table 1 . The multiplex PCR reactions were performed in a $10 \mu \mathrm{L}$ reaction mix containing $5 \mu \mathrm{L}$ of Multiplex PCR Master Mix (Qiagen), $0.2 \mu \mathrm{M}$ each primer, $10 \mu \mathrm{g}$ bovine serum albumin (New England Biolabs), $\mathrm{dH}_{2} \mathrm{O}$ (Qiagen) and $1.2 \mu \mathrm{L}$ extracted DNA. After the initial denaturing step at $95^{\circ} \mathrm{C}$ for $15 \mathrm{~min}$, amplification proceeded for 35 cycles at $94^{\circ} \mathrm{C}$ for $30 \mathrm{~s}, 56^{\circ} \mathrm{C}$ (for multiplex A) or $56.5^{\circ} \mathrm{C}$ (for multiplex B) for $1 \mathrm{~min} 30 \mathrm{~s}, 72{ }^{\circ} \mathrm{C}$ for $1 \mathrm{~min} 30 \mathrm{~s}$ and a final extension at $72{ }^{\circ} \mathrm{C}$ for $10 \mathrm{~min}$.

All PCRs included positive (target prey) and negative (sterile water instead of DNA) controls. The PCR products were separated and visualised on a $2 \%$ agarose gel stained with ethidium bromide (concentration $0.0750 \mu \mathrm{g} / \mathrm{mL}$ ) after $40 \mathrm{~min}$ at $120 \mathrm{~V}$. A PCR was considered positive by the presence of a band of the target size on the gel.

All samples were screened twice for the target prey using the same PCR conditions, and presence of bands in each reaction was counted as positive.

\section{Data analyses}

Statistical analyses were carried out using Statistica 9.1 (Statsoft Inc., 2010) and PRIMER 6 (2006). Cluster analyses with Bray-Curtis similarity index was employed for comparison of carabid species with respect to consumed earthworms from different ecological groups. Kruskal-Wallis ANOVA (comparison among multiple independent samples) as well as accompanying post hoc multiple comparison tests were used to analyse the relationship of beetle gut and body mass with prey type (three earthworm ecotypes), and check whether presence of earthworm DNA had any effect on gut mass. Spearman rank-order correlations between the body and gut weights were calculated only for the UK populations.

The predation data were presented as the number of beetles testing positive for earthworm consumption in the two seasons (late spring/early summer and autumn). Due to potential differences in prey DNA detectability among the different combinations of predator and prey species (e.g. 30), only the raw predation event data obtained from the positive PCR results are presented without further statistical analysis.

\section{RESULTS}

\section{Earthworm consumption by carabids in the field}

The foregut content of the field-caught carabid species was positive for earthworm species from each of the three ecological groups. Of all tested carabids $(\mathrm{N}=317), 168$ 
Table 2. Field-caught carabid species screened for three earthworm ecotypes; number of individual beetles tested and number of beetles testing positive for each prey group

Numbers in the brackets indicate number of individuals according to their sex ( $\odot$ female and $\hat{\sigma}$ males).

\begin{tabular}{|c|c|c|c|c|c|c|}
\hline \multirow[t]{2}{*}{ Species } & \multicolumn{2}{|l|}{ Sites } & \multicolumn{4}{|c|}{ Number of beetles testing positive for earthworms } \\
\hline & $\begin{array}{l}\text { (1,2 in Croatia } \\
3-5 \text { in the UK) }\end{array}$ & $\begin{array}{l}\text { No. ind. } \\
\left(+/ \delta^{\lambda}\right)\end{array}$ & All positives & $\begin{array}{l}\text { Anecic } \\
\left(+/ \delta^{\lambda}\right)\end{array}$ & $\begin{array}{l}\text { Epigeic } \\
\left(+/ \delta^{\lambda}\right)\end{array}$ & $\begin{array}{c}\text { Endogeic } \\
(\$ / \widehat{C})\end{array}$ \\
\hline Nebria brevicolis & $3,4,5$ & $87(33 / 54)$ & 35 & $23(10 / 13)$ & $19(11 / 8)$ & $9(3 / 6)$ \\
\hline Abax parallelus & 1,2 & $68(39 / 29)$ & 50 & $38(21 / 17)$ & $22(8 / 14)$ & $27(15 / 12)$ \\
\hline Abax parallelepipedus & $1,2,3,4,5$ & $63(20 / 43)$ & 34 & $25(7 / 18)$ & $13(5 / 8)$ & $13(4 / 9)$ \\
\hline Carabus nemoralis & 1,2 & $18(7 / 11)$ & 6 & $4(3 / 1)$ & $3(3 / 0)$ & $0 / 0$ \\
\hline C. ullrichi & 2 & $13(8 / 5)$ & 8 & $7(5 / 2)$ & $2(1 / 1)$ & $1(0 / 1)$ \\
\hline C. violaceus & $1,2,4,5$ & $9(6 / 3)$ & 4 & $1(1 / 0)$ & $1(1 / 0)$ & $4(4 / 0)$ \\
\hline Cychrus attenuatus & 1,2 & $7(2 / 5)$ & 5 & $4(1 / 3)$ & $0(0 / 0)$ & $3(2 / 1)$ \\
\hline Pterostichus madidus & $3,4,5$ & $7(6 / 1)$ & 3 & $2(1 / 1)$ & $2(2 / 0)$ & $1(1 / 0)$ \\
\hline Agonum sp. & 5 & $6(3 / 3)$ & 0 & $0 / 0$ & $0 / 0$ & $0 / 0$ \\
\hline C. convex & 2 & $6(6 / 0)$ & 3 & $2(2 / 0)$ & $2(2 / 0)$ & $0 / 0$ \\
\hline C. coriaceus & 2 & $6(3 / 3)$ & 4 & $4(3 / 1)$ & $2(1 / 1)$ & $1(1 / 0)$ \\
\hline C. intricatus & 1,2 & $6(3 / 3)$ & 4 & $2(2 / 0)$ & $2(0 / 2)$ & $1(0 / 1)$ \\
\hline Leistus fulvibarbis & 3,4 & $3(0 / 3)$ & 1 & $0 / 0$ & $0 / 0$ & $1(0 / 1)$ \\
\hline P. fasciatopunctatus & 2 & $3(2 / 1)$ & 2 & $1(1 / 0)$ & $1(1 / 0)$ & $1(0 / 1)$ \\
\hline C. problematicus & 4 & $2(1 / 1)$ & 0 & $0 / 0$ & $0 / 0$ & $0 / 0$ \\
\hline Molops piceus & 2 & $2(0 / 2)$ & 2 & $2(0 / 2)$ & $0 / 0$ & $2(0 / 2)$ \\
\hline P. melanarius & 3,4 & $2(1 / 1)$ & 1 & $1(0 / 1)$ & $0 / 0$ & $0 / 0$ \\
\hline P. transversalis & 1,2 & $2(0 / 2)$ & 2 & $2(0 / 2)$ & $0 / 0$ & $0 / 0$ \\
\hline Synuchus vivalis & 3,4 & $2(2 / 0)$ & 1 & $1(1 / 0)$ & $1(1 / 0)$ & $1(1 / 0)$ \\
\hline Aptinus bombarda & 1 & 1 & 0 & $0 / 0$ & $0 / 0$ & $0 / 0$ \\
\hline Notiophilus rufipes & 2 & 1 & 1 & 0 & 1 & 0 \\
\hline Bembidion nigricorne & 3 & $1(1 / 0)$ & 1 & $0 / 0$ & $0 / 0$ & $1(1 / 0)$ \\
\hline B. quadrimaculatum & 3 & $1(0 / 1)$ & 1 & $0 / 0$ & $1(0 / 1)$ & $0 / 0$ \\
\hline
\end{tabular}

(53\%) were positive for at least one earthworm species, and the $149(47 \%)$ individuals remaining were negative even after a second PCR screening. Most of the individual beetles $(\mathrm{N}=101)$ were positive for only one earthworm species, 48 individuals were positive for two prey species, 16 for three prey species and only three individuals showed positive for four earthworm prey species.

Of the 23 carabid species recorded at the five sites, only three species (Agonum sp., Carabus problematicus and Aptinus bombarda) were negative for earthworm species, while the rest were positive for at least one earthworm species (Table 2). Sixteen of the 23 carabid species were positive for anecic earthworms, 14 for epigeic earthworms and 14 for endogeic earthworms. Ten species were positive for earthworm species from all three ecotypes. Five species were positive for earthworms from two ecotypes (Table 2). When analysed for similarity using positive/negative data after screening the carabid guts for five earthworm species, most of the carabid beetles could be grouped into two sets of species with more than $50 \%$ of similarity (Bray-Curtis similarity): Pterostichus fasciatopunctatus, P. madidus, Carabus violaceus, $C$. convexus and $C$. coriaceus, together with two Abax species and Nebria brevicollis in one group; Carabus ullrichi, C. intricatus, Molopspiceus, Cychrus attenuatus and Synuchus vivalis in another group (Fig. 1).

Of all tested individual beetles, 77 and 41 were positive for A. longa and L. terrestris, respectively, both belonging to the anecic ecotypes, 66 were positive for $A$. chlorotica belonging to the endogeic ecotypes, and 55 and 18 individual beetles were positive for epigeic $L$. castaneus and $L$. rubellus, respectively. In addition, earthworms from all three ecotypes were predated in both seasons (91 individuals were positive in late spring/early summer and 77 in autumn) (Table 3, Fig. 2).

Overall, 148 female and 168 male beetles were collected from the five sites, of which 127 females and 130 males were positive for earthworms. Furthermore, all three groups of earthworms were predated by both sexes (Table 2, Fig. 3). Because the PCR data on carabid consumption was not adjusted by calculating the time of 


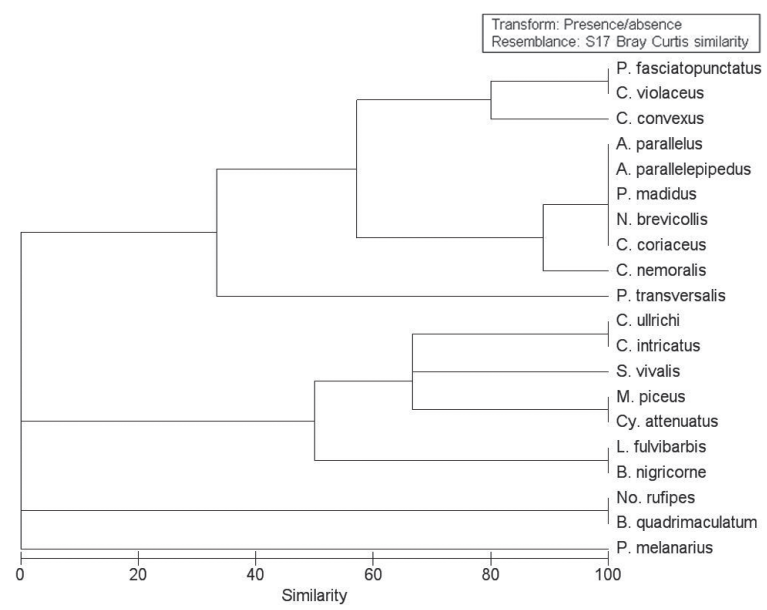

Fig. 1. Dendrogram depicting results of cluster analysis for similarity in carabid species according to the presencelabsence (PCR positivelnegative data) of each earthworm species in carabid guts using Bray-Curtis resemblance measure.

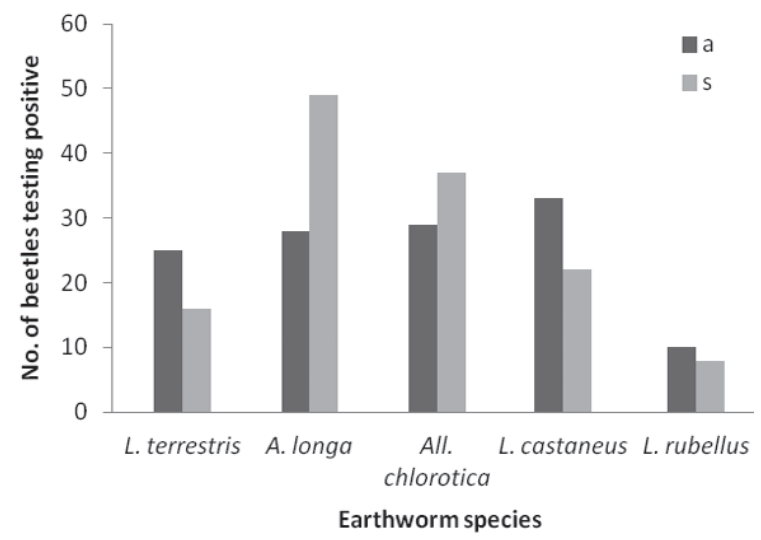

Fig. 2 Number of beetles testing positive in spring/summer (s) and autumn (a) for each earthworm species are shown as bars.

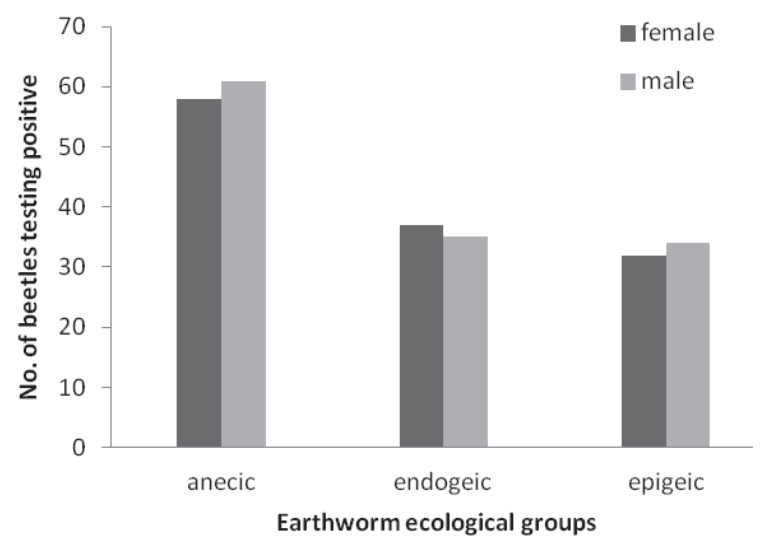

Fig. 3 Number offemale and male beetle individuals testing positive for earthworms classified in three ecological groups.

digestion for each predator-prey combination in this study, all proportions presented above should be considered only as approximate.
The gut weight was significantly correlated with the body weight of the individual beetles (Spearman correlation for all UK beetles tested: $\mathrm{N}=132, \mathrm{R}=0.48267$, and for UK beetles that tested positive: $\mathrm{N}=55, \mathrm{R}=0.555231$, at $\mathrm{p}<0.05)$. Kruskal-Wallis ANOVA did not show significant effect of presence of earthworms from three ecotypes on the gut weight or body weight of PCR-positive individual beetles $(\mathrm{H}$ for gut weight $(\mathrm{N}=55)=8.310491 \mathrm{p}=0.5985 ; \mathrm{H}$ for body weight $(\mathrm{N}=55)=6.172715 \mathrm{p}=0.8005)$.

\section{DISCUSSION}

This study confirm for the first time predation by carabid beetles on earthworms belonging to all three ecological groups (epigeic, endogeic and anecic) at the community level. Despite different spatial distributions of earthworms within the soil substrate, all three ecotypes of earthworms were detected as prey within the carabid assemblages in both seasons. All except three carabid species were positive for at least one earthworm species, demonstrating widespread predation on earthworms within the beetle community. Because the carabid assemblages considered in here were composed mainly of epigeic, nocturnal, and generalist predators, predation on anecic earthworms, which are active at night, when they collect leaves from the soil surface, was also expected and thus confirms our hypothesis. Interestingly, some carabid species such as $P$. melanarius or $C$. ullrich $i$ that can be active during the day (31) were positive for anecic earthworms.

The presence of anecic earthworms in the gut has also been confirmed by King et al. (7) for P. melanarius species. Our study further contributes to previous studies by screening guts from the entire community of carabid beetles for the presence of earthworms from the three ecological groups. In addition, we screened carabids from woodland communities, while the studies by Symondson et al. (24) and King et al. (7) were in arable fields.

An anecic $A$. chlorotica, was confirmed in the guts of the tested carabids but was not collected in the field. The reason this species was not observed in the field could be due to the digging and hand collecting method used in the topsoil layer, which can underestimate the abundance of the fauna located in the deeper soil layers. The results of King et al. (7) suggested that earthworms were predated proportionally to their field abundances. Similar findings were reported by Scheller (10), who detected aphid remains in proportion to the aphid field density for Bembidion lampros, Agonum dorsale, Pterostichus melanarius and Loricera pilicornis. Because all five earthworm species were detected in the carabid guts, we can indirectly confirm their presence in the field as well. Although indirect method, our PCR multiplex system could be a sensitive for detecting cryptic species via the gut content analysis of their predators (32).

The substantial number of individual beetles positive for $A$. chlorotica despite its strong defensive secretions (7) 
Table 3. Number of earthworms sampled in each field, in spring and autumn and their proportion (\%) within seasonal samples; and number of beetles tested positive for each prey species at each site and portion of (\%) carabid beetles testing positive in both seasons.

\begin{tabular}{|c|c|c|c|c|c|c|c|c|c|}
\hline \multirow[b]{2}{*}{$\begin{array}{l}\text { Earth-worm } \\
\text { species }\end{array}$} & \multirow[b]{2}{*}{ Plots } & \multicolumn{4}{|c|}{ Late Spring/Early Summer } & \multicolumn{4}{|c|}{ Autumn } \\
\hline & & $\begin{array}{c}\text { Prey } \\
\text { abundance in } \\
\text { the field }\end{array}$ & $\begin{array}{l}\% \text { of } \\
\text { prey in } \\
\text { spring }\end{array}$ & $\begin{array}{l}\mathrm{N} \text { (beetles } \\
\text { tested } \\
\text { positive) }\end{array}$ & $\begin{array}{l}\% \text { of beetles } \\
\text { positive in } \\
\text { spring }\end{array}$ & $\begin{array}{c}\text { Prey } \\
\text { abundance in } \\
\text { the field }\end{array}$ & $\begin{array}{c}\% \text { of } \\
\text { prey in } \\
\text { autumn }\end{array}$ & $\begin{array}{l}\mathrm{N} \text { (beetles } \\
\text { tested } \\
\text { positive) }\end{array}$ & $\begin{array}{l}\% \text { of beetles } \\
\text { positive in } \\
\text { autumn }\end{array}$ \\
\hline \multicolumn{10}{|c|}{ Lumbricus rubellus } \\
\hline & 1 & 4 & 4.88 & - & - & 9 & 0.12 & 2 & 2.60 \\
\hline & 2 & - & - & 1 & 1.10 & 13 & 0.17 & - & - \\
\hline & 3 & 3 & 3.66 & - & - & 3 & 0.04 & - & - \\
\hline & 4 & - & - & 2 & 2.20 & - & - & 1 & 1.30 \\
\hline & 5 & - & - & 5 & 5.49 & 1 & 0.01 & 7 & 9.09 \\
\hline \multicolumn{10}{|l|}{ L. castanea } \\
\hline & 1 & 2 & 2.44 & 1 & 1.10 & - & - & 13 & 16.88 \\
\hline & 2 & - & - & - & - & - & - & - & - \\
\hline & 3 & - & - & 2 & 2.20 & 1 & 0.01 & 8 & 10.39 \\
\hline & 4 & - & - & 3 & 3.30 & - & - & 1 & 1.30 \\
\hline & 5 & 3 & 3.66 & 16 & 17.58 & - & - & 11 & 14.29 \\
\hline \multicolumn{10}{|l|}{ L. terrestris } \\
\hline & 1 & 1 & 1.22 & 3 & 3.30 & 3 & 0.04 & 7 & 9.09 \\
\hline & 2 & - & - & 1 & 1.10 & 1 & 0.01 & 3 & 3.90 \\
\hline & 3 & 1 & 1.22 & 3 & 3.30 & 3 & 0.04 & 1 & 1.30 \\
\hline & 4 & - & - & - & - & - & - & - & - \\
\hline & 5 & - & - & 9 & 9.89 & - & - & 14 & 18.18 \\
\hline \multicolumn{10}{|c|}{ Allolobophora chlorotica } \\
\hline & 1 & - & - & 2 & 2.20 & - & - & 9 & 11.69 \\
\hline & 2 & - & - & 1 & 1.10 & - & - & - & - \\
\hline & 3 & - & - & 5 & 5.49 & - & - & 1 & 1.30 \\
\hline & 4 & - & - & 4 & 4.40 & - & - & - & 0.00 \\
\hline & 5 & - & - & 25 & 27.47 & - & - & 19 & 24.68 \\
\hline \multicolumn{10}{|c|}{ Aporrectodea longa } \\
\hline & 1 & - & - & 3 & 3.30 & - & - & 8 & 10.39 \\
\hline & 2 & - & - & 5 & 5.49 & - & - & 1 & 1.30 \\
\hline & 3 & - & - & 2 & 2.20 & - & - & 1 & 1.30 \\
\hline & 4 & - & - & 5 & 5.49 & - & - & 4 & 5.19 \\
\hline & 5 & - & - & 34 & 37.36 & - & - & 14 & 18.18 \\
\hline \multicolumn{10}{|c|}{ Satchellius mammalis } \\
\hline & 1 & - & - & - & - & 1 & 0.01 & - & - \\
\hline \multicolumn{10}{|l|}{ Eisenia fetida } \\
\hline & 1 & 1 & 1.22 & - & - & - & - & - & - \\
\hline & 4 & - & - & - & - & 1 & 0.01 & - & - \\
\hline & 5 & 1 & 1.22 & - & - & 1 & 0.01 & - & - \\
\hline \multicolumn{10}{|c|}{ Ap. smaragdina } \\
\hline & 4 & 20 & 24.39 & - & - & 8 & 0.10 & - & - \\
\hline & 5 & 5 & 6.10 & - & - & 3 & 0.04 & - & - \\
\hline \multicolumn{10}{|c|}{ Juveniles - unidentified } \\
\hline & 1 & 8 & 9.76 & - & - & 6 & 0.08 & - & - \\
\hline & 2 & 10 & 12.20 & - & - & 6 & 0.08 & - & - \\
\hline & 3 & 8 & 9.76 & - & - & 4 & 0.05 & - & - \\
\hline & 4 & 2 & 2.44 & - & - & 1 & 0.01 & - & - \\
\hline & 5 & 13 & 15.85 & - & - & 12 & 0.16 & - & - \\
\hline $\begin{array}{l}\text { Total abunda } \\
\text { earthworms in } \\
\text { Number of in } \\
\text { beetles tested }\end{array}$ & $\begin{array}{l}\text { of } \\
\text { e filed } \\
\text { idual } \\
\text { itive } \\
\end{array}$ & 82 & & 91 & & 77 & & 77 & \\
\hline
\end{tabular}


may demonstrate that not only $P$. melanarius but also some other carabid species have no aversion to consuming this species, as is the case with the secretions of some slugs $(33,34)$.

Some seasonality in the predation rates of different earthworm species were observed between the spring/ summer and autumn samples. A. longa and A. chlorotica were detected in carabid guts at higher rates in spring/ early summer than in autumn, which could be due to lower ambient temperatures that could slow the activity of carabids. On the other hand, Lumbricus species were detected in higher numbers in carabid guts in autumn than in the spring samples. Those species were also more abundant in the field in autumn, except for $L$. terrestris. As has already been noted, the sampling by hand sorting could also underestimate the populations of $L$. terrestris, an anecic earthworm species, in the field. Then again, chemical extraction methods also have biases and anecic species may be over-represented as the chemical going directly down their vertical burrows (35).

Among the carabids, the most abundant species in spring was $A$. parallelepipedus, with more individual beetles being positive for anecic $A$. longa than for endogeic or epigeic earthworms. In autumn, the most dominant species was $N$. brevicollis, with more individuals positive for epigeic $L$. castanea and for anecic $L$. terrestris.

The cluster analysis (Fig 1) grouped carabids according to their seasonal activities into spring active and autumn active carabids or biseasonal species groups. King et al. (7) observed significantly higher predation by $P$. melanarius on Aporrectodea caliginosa in July and on $A$. chlorotica in August than was expected (7). In the study by King et al. (7), P. melanarius showed the lowest predation rate on A. chlorotica in September but higher predation on L. rubellus and L. terrestris in September than in July. Because we did not perform feeding trials for each trophic combination, we could not adjust the raw PCR data to conduct preference analyses; our data are therefore indicative, reinforcing previous studies (e.g., 7) noting the need for further research to reveal if such patterns indicate selective predation or are a result of random feeding.

Specialisation on specific prey is infrequent among carabids (36). Therefore, as primarily generalist predators, carabids can be used in integrated pest management in agriculture and forestry and management systems that help to sustain the beetles in the field when pest numbers are low may be beneficial, such as ensuring healthy populations of non-pest alternative prey. A similar study confirmed collembolans as alternative prey that helps to sustain spiders in the field (37).

Three carabid species, Agonum sp., C. problematicus and Aptinus bombarda, were not positive for any of the five earthworm species, which may be due to only a few individuals being tested (6,2 and 1, respectively).

Carabid beetles, as well as their prey (earthworms, slugs, springtails, woodlice, etc.), are mainly soil fauna and oc- cupy different soil layers, from the deeper soil to the soil surface and the litter layer, where they feed or can be eaten by other animals. Therefore, different toxic compounds, primarily derivatives from various insecticides that end up in the soil, are taken up by earthworms or plants and then by herbivores, such as slugs, and may be transferred from the soil to higher trophic levels (e.g., 8, 38, 39). According to our study, earthworms from all three eco-types, appear as an important food source for carabids and thus can greatly contribute to the transfer of pollutants from the soil to other ecosystems (e.g., 8, 39, 41).

\section{Acknowledgements}

This work was supported by postdoctoral grant of the Croatian Science Foundation (Project No. 02.03/88) awarded to LSJ. The project was hosted by WOCS at Cardiff University. We would like to thank numerous colleagues for all their help in the field and in the laboratory, and to two reviewers for their valuable comments that help us to improve the manuscript.

\section{REFERENCES:}

1. SUNDERLAND KD 1975 The diet of some predatory arthropods in cereal crops. Journal of Applied Ecology 12: 389-396 https://doi.org/10.2307/2402171

2. THIELE HU 1977 Carabid beetles in their environments. Springer Verlag, Berlin, Heidelberg, New York, pp 369 https://doi.org/10.1007/978-3-642-81154-8

3. HENGEVELD R 1980 Polyphagy, oligophagy and food specialization in ground beetles (Coleoptera, Carabidae). Netherlands Journal of Zoology 30: 564-584 https://doi.org/10.1163/002829679X00197

4. SUNDERLAND KD, SUTTON SL 1980 A serological study of arthropod predation on terrestrial isopods in a dune grassland ecosystem. Journal of Animal Ecology 49/3: 987-1004 https://doi.org/10.2307/4240

5. SYMONDSON WOC, GLEN DM, ERICKSON ML, LIDDELL JE, LANGDON CJ 2000 Do earthworms help to sustain the slug predator Pterostichus melanarius (Coleoptera: Carabidae) within crops? Investigations using monoclonal antibodies. Molecular Ecology 9: 1279-1292 https://doi.org/10.1046/j.1365-294x.2000.01006.x

6. SYMONDSON WOC, CESARINI S, DODD P, HARWOOD J 2006 Biodiversity vs. biocontrol: positive and negative effects of alternative prey on control of slugs by carabid beetles. Bulletin of Entomological Research 96: 637-645 https://doi.org/10.1017/BER2006467

7. KING RA, VAUGHAN IP, BELL JR, BOHAN DA, SYMONDSON WOC 2010 Prey choice by carabid beetles feeding on an earthworm community analysed using species- and lineage-specific PCR primers. Molecular Ecology 19: 1721-1732 https://doi.org/10.1111/j.1365-294X.2010.04602.x

8. ŠERIĆ JELASKA L, JURASOVIĆ J, BROWN SD, VAUGHAN PI, SYMONDSON WOC 2014 Molecular field analysis of trophic relationships in soil-dwelling invertebrates to identify mercury, lead and cadmium transmission through forest ecosystems. Molecular ecology 23: 3755-3766 https://doi.org/10.1111/mec.12566

9. ŠERIĆ JELASKA L, FRANJEVIĆ D, JELASKA SD, SYMONDSON WOC 2014 Prey detection in carabid beetles in woodland ecosystems by PCR analyses of gut content. European journal of entomology 111(5): 631-638 
10. SCHELLER HV 1984 The role of ground beetles (Carabidae) as predators on early populations of cereal aphid in spring barley. Journal of Applied Entomology 97(1-5): 451-463 https://doi.org/10.1111/j.1439-0418.1984.tb03775.x

11. CHEN Y, GILES KL, PAYTON ME, GREENSTONE MH 2000 Identifying key cereal aphid predators by molecular gut analysis. Molecular Ecology 9: 1887-1898 https://doi.org/10.1046/j.1365-294x.2000.01100.x

12. HARWOOD JD, SUNDERLAND KD, SYMONDSON WOC 2004 Prey selection by linyphiid spiders: molecular tracking of the effects of alternative prey on rates of aphid consumption in the field. Molecular Ecology 13, 3549-3560 https://doi.org/10.1111/j.1365-294X.2004.02331.x

13. HARWOOD JD, DESNEAUX N, YOO HJS, ROWLEY DL, GREENSTONE MH, OBRYCKI JJ, O'NEIL RJ 2007 Tracking the role of alternative prey in soybean aphid predation by Orius insidiosus: a molecular approach. Molecular Ecology 16: 4390 4400 https://doi.org/10.1111/j.1365-294X.2007.03482.x

14. NASH MA, THOMSON LJ, HORNE PA, HOFFMAN AA 2008 Notomus gravis (Chaudoir) (Coleoptera: Carabidae) predation of Deroceras reticulatum Müller (Gastropoda: Agrolimacidae), an example of fortuitous biological control. Biological Control 47: 328-334 https://doi.org/10.1016/j.biocontrol.2008.08.013

15. HATTELAND BA, GRUTLE K, MONG CE, SKARTVEIT J, SYMONDSON WOC, SOLHØY T 2010 Predation by beetles (Carabidae, Staphylinidae) on eggs and juveniles of the Iberian slug Arion lusitanicus in the laboratory. Bulletin of Entomological research 100(5):559-567 https://doi.org/10.1017/S0007485309990629

16. ESKELSON MJ, CHAPMAN EG, ARCHBOLD DD, OBRYCKI JJ, HARWOOD JD 2011 Molecular identification of predation by carabid beetles on exotic and native slugs in a strawberry agroecosystem. Biological Control 56: 245-253 https://doi.org/10.1016/j.biocontrol.2010.11.004

17. BOREAU DE ROINCE C, LAVIGNE C, RICARD J, FRANCK P, BOUVIER J, GARCIN A, SYMONDSON WOC 2012 Predation by generalist predators on the codling moth versus a closelyrelated emerging pest the oriental fruit moth: a molecular analysis. Agricultural and Forest Entomology 14: 260-269 https://doi.org/10.1111/j.1461-9563.2011.00564.x

18. HŮRKA K 1996 Carabidae of the Czech and Slovak Republics. Kabourek, Zlin, pp 565

19. SIMS RW, GERARD BM 1985 Earthworms: Keys and Notes for the Identification and Study of the Species. Linnaean Society of London, Estuarine and Brackish-Water Sciences Association, Brill Archive, pp 171

20. JEFFERY S, GARDI C, JONES A, MONTANARELLA L, MARMO L, MIKO L, RITZ K, PERES G, RÖMBKE J, VAN DER PUTTEN HW (EDS.) 2010 European Atlas of Soil Biodiversity. European Commission, Publications Office of the European Union, Luxembourg, pp 129

21. TURIN H, PENEV L, CASALE A 2003 The Genus Carabus in Europe. Pensoft, Sofia-Moscow, pp 511

22. PAILL W 2000 Slugs as a prey for larvae and imagines of Carabus violaceus L. (Coleoptera, Carabidae) pp. 221-222. In Brandmaye P, Lovei GL, Brandmayr TZ, Casale A and Vigna Taglianti A (eds.), Natural history and applied ecology of carabid beetles. Sofia, Bulgaria, Pensoft Publishers.

23. ZAIDI RH, JAAL Z, HAWKES NJ, HEMINGWAY J, SYMONDSON WOC 1999 Can multiple-copy sequences of prey DNA be detected amongst the gut contents of invertebrate predators? Molecular Ecology 8: 2081-2087 https://doi.org/10.1046/j.1365-294x.1999.00823.x

24. SYMONDSON WOC 2002 Molecular identification of prey in predator diets. Molecular Ecology 11: 627-641 https://doi.org/10.1046/j.1365-294X.2002.01471.x
25. HARPER GL, KING RA, DODD CS, HARWOOD JD, GLEN DM, BRUFORD MW, SYMONDSON WOC 2005 Rapid screening of invertebrate predators for multiple prey DNA targets. Molecular Ecology 14: 819-827 https://doi.org/10.1111/j.1365-294X.2005.02442.x

26. MRŠIĆ N 1997 Živali naših tal. Uvod v pedozoologijo-sistematika in ekologija s splošnim pregledom talnih živali. Tehniška založba Slovenije, Ljubljana, pp 416

27. FREUDE H, HARDE KW, LOHSE GA, KLAUSNITZER B 2004 Die Käfer Mitteleuropas, Band 2, Spectrum, Elsevier, München, pp 521

28. LUFF ML 2007 The Carabidae (ground beetles) of Britain and Ireland. Carl Hildebrand Lindroth, Royal Entomological Society of London, p 247

29. FOLMER O, BLACK M, HOEH W, LUTZ R, VRIJENHOEK R 1994 DNA primers for amplification of mitochondrial cytochrome coxidase subunit I from diverse metazoan invertebrates. Molecular Marine Biology and Biotechnology 3: 294-299

30. GAGNON AÈ, DOYON J, HEIMPEL GE, BRODEUR J (2011) Prey DNA detection success following digestion by intraguild predators: influence of prey and predator species. Molecular Ecology Resources, 11:1022-32 https://doi.org/10.1111/j.1755-0998.2011.03047.x

31. TUF IH, DEDEK P, VESELY M 2012 Does the diurnal activity pattern of carabid beetles depend on season, ground temperature and habitat? Arch. Biol. Sci., Belgrade, 64 (2): 721-732

32. BOYER S, CRUICKSHANK RH, WRATTEN SD 2015 Faeces of generalist predators as 'biodiversity capsules': A new tool for biodiversity assessment in remote and inaccessible habitats. Food Webs 3: 1-6 https://doi.org/10.1016/j.fooweb.2015.02.001

33. SYMONDSON WOC 1997 Does Tandonia budapestensis (Mollusca: Pulmonata) contain toxins? Evidence from feeding trials with the slug predator Pterostichus melanarius (Coleoptera: Carabidae). Journal of Molluscan Studies 63: 541-545 https://doi.org/10.1093/mollus/63.4.541

34. FOLTAN P 2004 Influence of slug defence mechanisms on the prey preferences of the carabid predator Pterostichus melanarius (Coleoptera: Carabidae). European Journal of Entomology 101: 359-364 https://doi.org/10.14411/eje.2004.050

35. COLEMAN, D. C., CROSSLEY, D. A., \& HENDRIX, P. F. (2004). Fundamentals of Soil ecology (2nd ed.). Elsevier Academic Press, San Diego, pp 386

36. TRAUTNER J, GEIGENMÜLLER K 1987 Tiger beetles, ground beetles - Illustrated key to the Cicindelidae and Carabidae of Europe. J. Margraf Verlag, Aichtal, Germany, pp 488

37. AGUSTÍN, SHAYLER SP, HARWOOD JD, VAUGHAN IP, SUNDERLAND KD, SYMONDSON WOC 2003 Collembola as alternative prey sustaining spiders in arable ecosystems: prey detection within predators using molecular markers. Molecular Ecology 12: 3467-3475

https://doi.org/10.1046/j.1365-294X.2003.02014.x

38. HALLMANN CA, FOPPEN RPB, VAN TURNHOUT CAM, DE KROON H, JONGEJANS E 2014 Declines in insectivorous birds are associated with high neonicotinoid concentrations. $\mathrm{Na}$ ture 511: 341-343 https://doi.org/10.1038/nature13531

39. DOUGLAS MR, ROHR JR, TOOKER JF 2015 Neonicotinoid insecticide travels through a soil food chain, disrupting biological control of non-target pests and decreasing soya bean yield. Journal of Applied Ecology 52(1): 250-260 https://doi.org/10.1111/1365-2664.12372

40. NAHMANI J, HODSON ME, BLACK S 2007 A review of studies performed to assess metal uptake by earthworms. Environmental Pollution 145: 402-424 https://doi.org/10.1016/j.envpol.2006.04.009

41. SIZMUR T, HODSON ME 2009 Do earthworms impact metal mobility and availability in soil? A review. Environmental Pollution 157: 1981-1989 https://doi.org/10.1016/j.envpol.2009.02.029 
Appendix 1. Field-caught carabid species screened for five earthworm species and number of individual species testing positive for each prey species.

\begin{tabular}{|c|c|c|c|c|c|}
\hline & 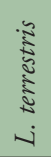 & $\begin{array}{l}5 \\
5 \\
5 \\
\end{array}$ & $\begin{array}{l}\text { s. } \\
\text { ș } \\
\text { s. } \\
\text { - }\end{array}$ & 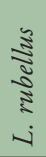 & 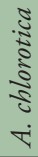 \\
\hline A. parallelepipedus & 7 & 18 & 10 & 3 & 13 \\
\hline A. parallelus & 15 & 23 & 17 & 5 & 27 \\
\hline B. nigricorne & 0 & 0 & 0 & 0 & 1 \\
\hline B. quadrimaculatum & 0 & 0 & 1 & 0 & 0 \\
\hline C. convexus & 0 & 2 & 0 & 2 & 0 \\
\hline C. coriaceus & 1 & 3 & 1 & 1 & 1 \\
\hline C. intricatus & 0 & 2 & 2 & 0 & 1 \\
\hline C. nemoralis & 2 & 2 & 1 & 2 & 0 \\
\hline C. ullrichi & 0 & 7 & 2 & 0 & 1 \\
\hline C. violaceus & 0 & 1 & 0 & 1 & 4 \\
\hline Cy. attenuatus & 1 & 3 & 0 & 0 & 3 \\
\hline L. fulvibarbis & 0 & 0 & 0 & 0 & 1 \\
\hline M. piceus & 1 & 1 & 0 & 0 & 2 \\
\hline No. rufipes & 0 & 0 & 1 & 0 & 0 \\
\hline N. brevicollis & 11 & 12 & 17 & 2 & 9 \\
\hline P. transversalis & 0 & 2 & 0 & 0 & 0 \\
\hline P. fasciatopunctatus & 0 & 1 & 0 & 1 & 1 \\
\hline P. madidus & 1 & 1 & 1 & 1 & 1 \\
\hline P. melanarius & 1 & 0 & 0 & 0 & 0 \\
\hline S. vivalis & 1 & 0 & 1 & 0 & 1 \\
\hline
\end{tabular}


